\title{
Haemoglobin D Trait-An Uncommon Haemoglobinopathy in Chattogram: A Case Report
}

Razia Sultana ${ }^{*}$

Tani Gosh ${ }^{1}$

'Department of Laboratory Medicine Chattagram Maa-O-Shishu Hospital Medical College Chattogram, Bangladesh.

\section{*Correspondence to: \\ Dr. Razia Sultana}

Professor

Department of Laboratory Medicine

Chottagram Maa-O-Shishu Hospital Medical College

Chattogram, Bangladesh.

Mobile : +8801711909053

Email : razialucky24@gmail.com

Date of Submission : 20.12 .2020

Date of Acceptance : $\quad 28.01 .2021$

www.banglajol.info/index.php/CMOSHMCJ

\begin{abstract}
This case presents haemoglobin D Trait $(H b-D)$ which is a rare disease in Bangladesh. It is a heterozygous state for haemoglobin D who came to Laboratory Medicine Department of Chattogram Maa Shishu-O-General Hospital (CMSOGH) for heamoglobin electrophoresis. Our patient was 9 years old girl from Noakhali, Bangladesh. She was clinically silent with no splenomegaly. Her peripheral blood film was microcytic hypochromic anaemia and Capillary Electrophoresis (CE) of $\mathrm{Hb}$ revealed $\mathrm{Hb} D$ Trait. On family screening her father was $\mathrm{Hb}$ E trait, mother was $\mathrm{Hb} D$ trait and younger sister turned out normal $\mathrm{Hb}$ study. Compound heterozygosity for haemoglobin $D$ and haemoglobin $E$ may be present in subsequent pregnancy of her mother.
\end{abstract}

Key words: Heterozygosity; Hb D trait; Haemoglobinopathy.

\section{INTRODUCTION}

Thalassaemia is one of the most common hereditary disorders in the world including Bangladesh. This is a major health problem particularly in the developing countries where the resources are limited. World Health Organization (WHO) estimates that at least $6.5 \%$ of the world populations are carriers of different inherited disorders of haemoglobin. In Bangladesh the commonest varieties of Thalassaemia are Beta Thalassaemia trait (4.1\%) and Haemoglobin E trait $(6.1 \%)^{1}$. Haemoglobin D and Haemoglobin $\mathrm{S}$ are though rare but can be prevalent in several populations in the different parts of Southern Asia.

$\mathrm{Hb}$ D, a Heamoglobin variant, occurs mainly in North West India, Pakistan and Iran. It is also found sporadically in Blacks and Europeans, the latter usually coming from countries that have had close associations with India in the past ${ }^{2}$. Hb D-Punjab and $\mathrm{Hb}$ D-Los Angeles is identical haemoglobin. Hb D-Punjab occurs in about 3\% of the population in northwest India and $\mathrm{Hb}$ D-Los Angeles is seen in fewer than $2 \%$ of African Americans ${ }^{3}$. $\mathrm{HbD}$ differs structurally from normal $\mathrm{Hb} \mathrm{A}$ at 121 position on chain were glutamine is replaces glutamic acid $\left(\alpha, \beta_{2}{ }^{121 \mathrm{Glu}-\mathrm{Gln}}\right)$. Hb D gene can be detected by DNA amplification and globin chain analysis ${ }^{4,5}$. Hb D occurs in four forms: heterozygous $\mathrm{Hb} \mathrm{D}$ trait, $\mathrm{Hb} \mathrm{D}$ - thalassaemia, HbS-D disease and rare homozygous $\mathrm{Hb} \mathrm{D}$ disease, which is usually associated with mild haemolytic anaemia and mild to moderate splenomegaly ${ }^{6,7}$. Hence we report a case of $\mathrm{Hb} \mathrm{D}$ trait, an uncommon haemoglobinopathies in Bangladesh. The aim of reporting this case is that the treatment is simple but genetic counseling is important for identifying the reproductive risks of the family.

\section{CASE REPORT}

A 9 year old girl from Noakhali attended on 20th September 2020 to the Child Outpatient Department of CMSOGH for having generalized weakness and anorexia. There were no other significant complaints. Her family history was not contributory and her mother was 3 months pregnant. On examination she had mild pallor, spleen was not palpable and no other organomegaly and lymphadenopathy were present. 
Laboratory examination revealed Haemoglobin $10.9 \mathrm{~g} / \mathrm{dl}$, RBC 5.36 million/cmm, MCV 63.1fl, MCH 20.3pg, MCHC 32.2g/dl, RDW-CV 15.4\%, Microcytic hypochromic anaemic blood film, Capillary Electrophoresis (CE) of $\mathrm{Hb}$ showed $\mathrm{HbA} 85.5 \%, \mathrm{HbF}$ $1.0 \%, \mathrm{Hb} \mathrm{D} 11 \%, \mathrm{HbA}_{2} 2.6 \%$ indicating diagnosis of $\mathrm{HbD}$ trait (Figure-1) . After getting such report of the patient the electrophoresis of her parents and sibling were done. Her mother aged 28 years, $3^{\text {rd }}$ gravida, found moderately anaemic, $\mathrm{Hb} 9.4 \mathrm{~g} / \mathrm{dl}$, RBC 4.52 million/cmm, MCV 64.4fl, MCHC 32.3g/dl, RDWCV 16.4\%, Microcytic hypochromic anaemic blood film, CE showed $\mathrm{HbA} 86.0 \%, \mathrm{HbD} 11.5 \%, \mathrm{HbA}_{2} 2.5 \%$ diagnosed as HbD Trait (Figure-2). Her father aged 38 years old had no remarkable physical finding. Fathers $\mathrm{Hb} 14.9 \mathrm{~g} / \mathrm{dl}$, RBC 6.38 million/cmm, MCV 71.0 fl, MCH 23.4pg, MCHC 32.9g/dl, RDWCV 14.2\%, non specific blood film, Capillary electrophoresis showed $\mathrm{HbA} 72.5 \%, \mathrm{HbE} 23.8 \%, \mathrm{HbA}_{2} 3.7 \%$ diagnosed as $\mathrm{HbE}$ trait (Figure-2). Her sister aged 7 years had normal pattern of $\mathrm{CBC}$, blood film and $\mathrm{CE}$ (Table I).

After family screening of the girl conforms she is a case of heterozygous state for $\mathrm{Hb} \mathrm{D}$. Her family pedigree is shown in Figure 2 and blood parameters of the family shown in Table I.

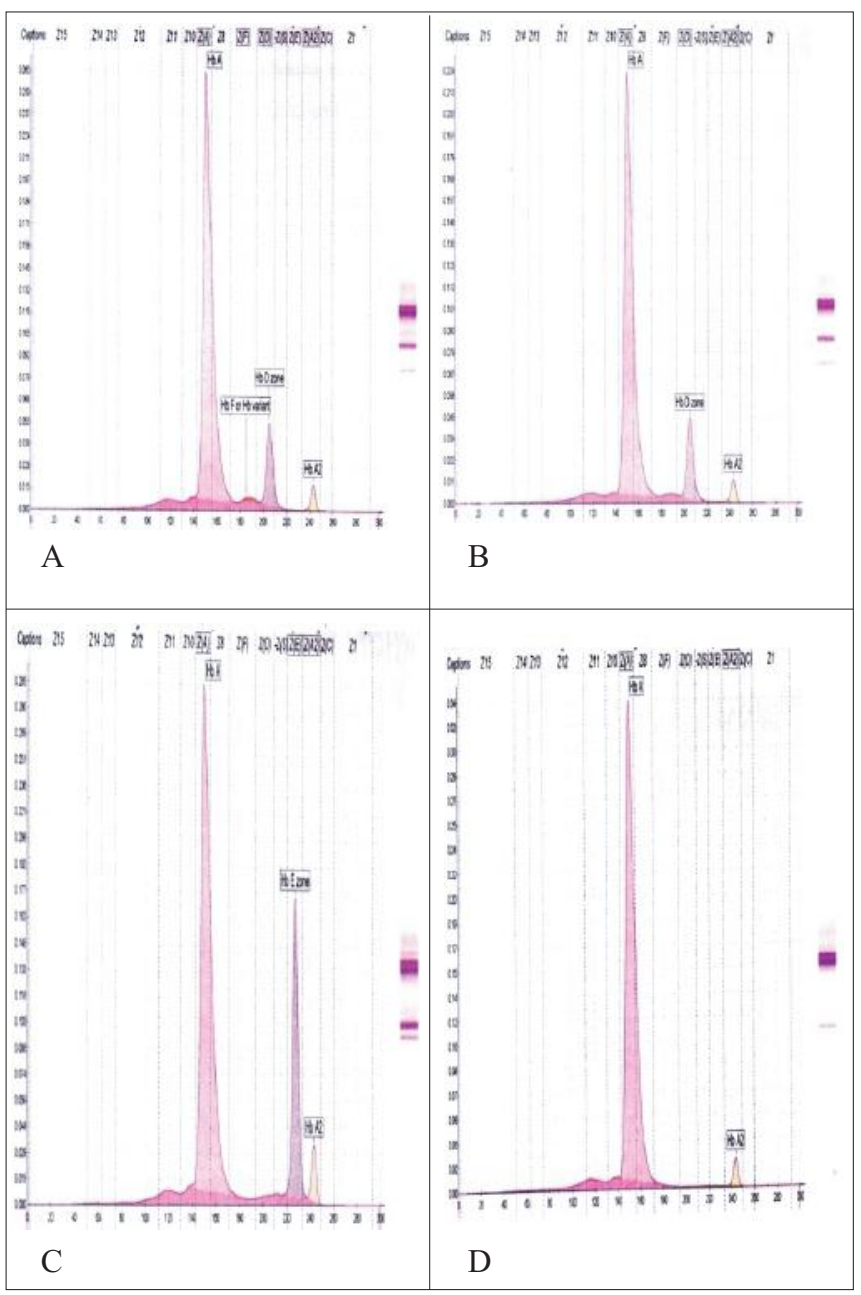

Figure 1: Hb pattern of the case (A) Her Mother (B) Father (C) Sister (D).

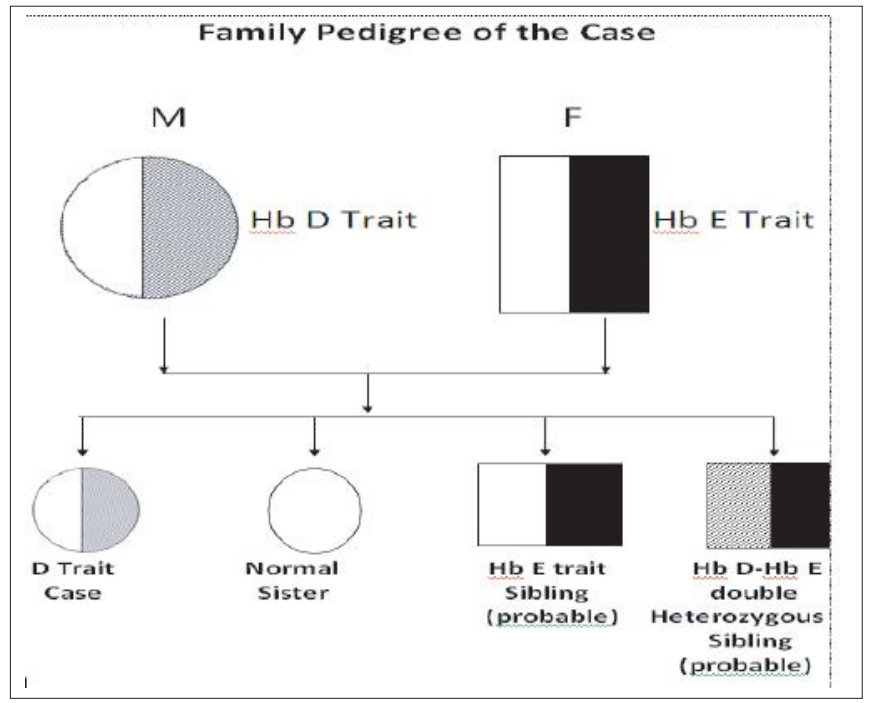

Figure 2 : Family Pedigree of the case.

Table I : Hematological parameters of the patient and her family.

\begin{tabular}{|c|c|c|c|c|c|c|c|c|c|c|c|}
\hline elat & $\begin{array}{l}\mathrm{Hb} \\
(\mathrm{g} / \mathrm{dll})\end{array}$ & $\begin{array}{l}\text { RBC } \\
\text { Count } \\
\left(\times 10^{12} / L\right)\end{array}$ & $\begin{array}{l}\text { MCV MCH } \\
\text { (fl) (pg) }\end{array}$ & $\begin{array}{l}\text { MCHC } \\
(g / d \text { dil })\end{array}$ & $\begin{array}{l}\text { RDW } \\
(\%)\end{array}$ & PBF & $\begin{array}{l}\mathrm{HbA} \\
(\%)\end{array}$ & $\begin{array}{l}\mathrm{HbA}_{2} \\
(\%)\end{array}$ & $\begin{array}{l}\text { Hb E } \\
(\%)\end{array}$ & $\begin{array}{l}\text { Hb D } \\
(\%)\end{array}$ & $\begin{array}{l}\mathrm{HbF} \\
(\%)\end{array}$ \\
\hline & 10.9 & 5.36 & 20.3 & 32) & 154 & MHA & 85.4 & 2.6 & & 11.0 & 1.0 \\
\hline Mother & 9.4 & 4.5 & $4.4 \quad 20.8$ & 32.3 & 16.4 & MHA & 86.0 & 2.5 & . & 11.5 & \\
\hline the & 14.9 & 6.38 & $71.0 \quad 23.4$ & 32.9 & 14.2 & NSF & 72.5 & 3.7 & 23.8 & & \\
\hline ter & 12.6 & 5.26 & $73.6 \quad 24.0$ & 32.6 & 15.8 & NSF & 97.2 & 2.8 & . & & \\
\hline
\end{tabular}

Ethical Issue: Written and informed consent were taken from the patient as well as guardian of the patient for publishing this article.

\section{DISCUSSION}

$\mathrm{Hb} \mathrm{D}$ is uncommon in Bangladesh but few cases have been reported $^{8}$. In our case as father is $\mathrm{HbE}$ trait and mother is $\mathrm{HbD}$ trait possible siblings will be $\mathrm{Hb} \mathrm{D}$ trait, which is the patient, may be normal who her sister is, other possibility will be $\mathrm{HbE}$ trait or compound heterozygosity for Haemoglobin D and haemoglobin E. Population demographics are changing with inter mixing so $\mathrm{Hb} \mathrm{D}$ trait should no longer confined to north west India \& Pakistan. Haematological parameters of our case and her family are interesting but clinically not significant. Genetic counseling should be done for determining any possible reproductive risk factors. We suggest red cell indices and CE are sufficient for screening of $\mathrm{Hb} \mathrm{D}$ trait in resource poor setting.

\section{CONCLUSION}

Patient with $\mathrm{Hb} \mathrm{D}$ trait clinically asymptomatic, usually detected during investigation.

\section{DISCLOSURE}

All the authors declared no competing interest. 


\section{REFERENCES}

1. Khan W, Banu B. Prevalence of Beta thalassaemia trait and $\mathrm{Hb}$ E trait in Bangladeshi school children and health burden of thalassaemia in our population. DS (Child) H J 2005; 21 (1) : 1-7.

2. Firkin F, Chesterman C, Penington D, Rush B. Disorders of Hemoglobin Structure and Synthesis. de Gruchi's Clinical Hematology in Medical Practice. $5^{\text {th }}$ ed. Oxford: Blackwell Science; 1996.p.137-137.

3. Tim R.Randolph, in Rodak's Hematology (Edition). 2020.

4. Zeng YT, Huang SZ, Zhou LD, Huang HJ, Jiao CT, Tang ZG et al. Identification of hemoglobin D Punjab by gene mapping. Hemoglobin. 1986;10: 87-90.

5. Zeng YT, Huang SZ, REn ZR, Li HJ. Identification of HbD-Punjab gene: Application of DNA amplication in the study of abnormal hemoglobins. Am J Med Genet 1989; 44:866-869.

6. Lukens JN. The Abnormal Hemoglobins: General Principles. In .Lee GR, Foerster J, Lukens J, Paraskevas F, Greer JP, Rodgers GM, editors. Wintrobe's Clinical Hematology. Tenth ed. Baltimore: Lippincott Williams \& Wilkins. 1998;1329-1345.

7. Ozsoylu S. Homozygous hemoglobin D Punjab. Acta Haematol. 1970; 43:353-359.

8. Rahman MM, Khan L, Begum M, Saha D, Khan AA. Compound heterozygosity for hemoglobin D and hemoglobin E. Bangabandhu Sheikh Mujib Med Univ J. 2016; 9: 214-216. 